\title{
Resenha
}

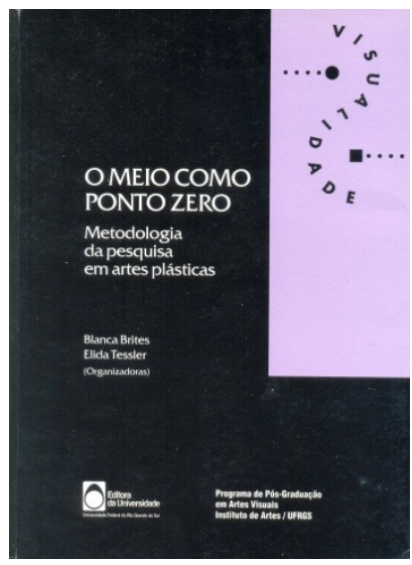

BRITES, Blanca, TESSLER, Elida (organizadoras).

0 meio como ponto zero. Metodologia da pesquisa em artes plásticas.

Porto Allegre:

Editora da Universidade UFRGS, 2002.

\section{Apontando os tópicos}

\author{
Silvia Carvalho ${ }^{1}$
}

O livro "O meio como ponto zero", apresenta diferentes conceitos de pesquisadores na área das artes plásticas no âmbito universitário. Tecendo idéias, sugestões, conceitos a fim de articular a construção de um pensamento prático-teórico que envolve 0 artista- pesquisador. Nesse texto vou citar algumas colocações relevantes de alguns dos pesquisadores participantes.

\footnotetext{
${ }^{1}$ Artista visual, acadêmica do curso de Bacharelado em Artes Plásticas da UDESC/CEART.
} 
Jean Lancri, artista plástico e professor na Universidade de Paris I- Pantheón/Sorbonne. Levanta a questão da dificuldade do começo para quem se aventura na pesquisa em artes plásticas mesmo que seja um recomeço. E sugere que "se" entre no assunto pelo meio, ou seja, deve partir do meio de uma prática, de uma vida, de um saber, de uma ignorância do que se crê saber melhor.

Porque "a arte insere-se a meio caminho entre o conhecimento científico e o pensamento mítico ou mágico". E continua dizendo que um pesquisador em artes plásticas, opera sempre no campo do conceitual e do sensível, entre teoria e prática, entre razão e sonho. Mas que não impede que a razão se ponha a sonhar e o sonho a raciocinar. Portanto trata-se de operar no constante vaivém entre esses diferentes registros.

Uma tese em artes plásticas tem por originalidade entrecruzar uma produção plástica com uma produção textual; ela não se completa quando não consegue ligá-las por travas. A parte da prática plástica ou artística, sempre pessoal, deve ter a mesma importância da parte escrita, uma não é indissociável da outra. Debater, examinar, criticar, avaliar seus trabalhos e de outros também é fator de suma importância. Comprometer-se com armas e bagagens em sua pesquisa. Armas de desejo, bagagens de linguagens, de saberes e corpo. Sobretudo de corpo, inclusive de cabeça, evidentemente. 0 uso da razão na pesquisa em artes plásticas 
deve ser temperado por certa dose de dúvida. Outra questão é a de colocar o problema do projeto, conceitos que prevêem, tanto quanto possível, a trajetória do futuro trajeto. A redação no texto, que constitui a maior parte escrita da tese, deve buscar a maior precisão no pensamento. 0 pesquisador em artes deve penetrar em seu objeto de estudo com temeridade. O conhecimento dos conceitos vai, portanto, de par com o reconhecimento do campo em que esses conceitos se mostram operacionais.

Icléia Cattani (pesquisadora, professora e crítica de arte) coloca a seguinte questão para o artista-pesquisador: "Como pensar a obra com pesquisa, dentro dos critérios acadêmicos? $E$ responde: “Não tentar "lê-la", mas vê-la em seus elementos materiais próprios. Situá-la em seu lugar". Para ela, a pesquisa de arte buscará o rigor de análise que the permita qualificar-se como pesquisa, ligada á sensibilidade do olhar e fundamentação teórica. Ela fala da importância de um chamado "Diário de bordo", onde serão feitas anotações com intenções, dúvidas, processos criativos. Esse procedimento é bastante relevante durante a elaboração do trabalho artístico. Pois é necessário que o pesquisador reconheça a importância do seu olhar para o desenvolvimento da reflexão.

Hélio Fervenza (Artista plástico, professor e pesquisador em artes visuais) levanta a questão da importância de reflexão nas seguintes perguntas: "Para onde olha nosso 
trabalho? 0 que ele olha? Como olhar para o assunto que temos a desenvolver? De onde olhálo? Como olhar para nossas referências, para as informações que possam nos auxiliar a situar nosso percurso?" e dá alguns exemplos da mostra intitulada "Olho Mágico", realizada por ele em junho de 1997, na Galeria do Centro Integrado de Cultura em Florianópolis, durante o festival de inverno da Udesc.

Justo Pastor Mellado (Crítico de arte, professor e curador independente) aponta o fator da descrição da obra em curso, mas já estruturada, como de grande importância. Descrição esta entendida como dissecação, compreendida como uma reconstrução icônica, um passo que envolve, para ele, a representação da corporalidade. "Isto é, exercícios de descrição posicional”.

Elida Tessler (Artista plástica, pesquisadora e professora) faz lembrar a importância da boa articulação entre o projeto de pesquisa e a sua realização, unindo produção e reflexão, por meio da pesquisa sistemática, científica, na qual podemos chagar á "cicatriz", costurando os fragmentos de um complexo processo que faz parte da criação. Ela questiona o lugar do artista plástico: "que lugar é esse que ocupamos, e o que fazemos, por exemplo, na universidade? Enfim, como se dá pesquisa de artes plásticas na universidade?". E diz que a arte contemporânea tem um caráter andarilho, pois percorre distintas áreas do saber, ao mesmo tempo que tenta superar limites. 
Tessler também cita a palavra entrecruzamento com, para ela, uma sintonia entre produção e reflexão, entre "teoria" e "prática", entre arte e pensamento, pois "nossas dúvidas tornam-se matéria- prima de nossas pesquisas".

Sandra Rey (artista plástica, Professora e pesquisadora) atenta para o fato de que para a pesquisa muito mais que saber respostas é colocar questões. E que o desafio constante para o artista-pesquisador é provocar um avanço, ou talvez, ou um deslocamento.

Rey fala de "conceitos operatórios" explicando que "cada procedimento instaurador da obra implica a operacionalização de um conceito", isto é, "operar, realizar a obra tanto no nível prático como teórico". Para ela a pergunta $o$ quê deve ser substituída por como: "como isso foi feito? Como isso produz sentido?" e coloca uma citação de Heidegger para ilustrar sua idéia. "A obra instaura um mundo, conforme Heidegger (1987) e amplia a percepção e o sentido ordinário que se tem das coisas, dos objetos e das situações".

Outro termo utilizado por ela é "utopia". E explica que "a pesquisa em arte aproxima-se da utopia, como algo que não tem lugar, não possui ainda um lugar definido no tempo presente". E faz uma lista de alguns instrumentos para análise poética da própria obra e de outros artistas: 
a) verbalizar: falar sobre o trabalho, explicar para outras pessoas o que se está fazendo.

b) Criar estratégias: verificar direções que a pesquisa sugere, podendo descartá-las e retomá-las mais adiante. Manter um diário de anotações.

c) Estar atento às ambigüidades: na obra os contrários também podem se unir. Ficar atento, abrir a percepção ao que à primeira vista parece „sem importância”.

d) Instrumentos para a pesquisa teórica: Coletar dados das mais diversas formas. Procurar sempre que possível as informações nas fontes.

e) Conceitualizar: fazer uso de obras teóricas utilizando-se dos vários campos interdisciplinares, mesclando-os.

f) As análises comparativas: tarefa de aproximar o que parece muito diferente e de afastar o que parece muito semelhante.

g) Redigir pequenos ensaios: realizar pequenos exercícios de redação desde a introdução.

h) Apresentar claramente suas idéias: na redação final, organizar bem as idéias. $\mathrm{Na}$ introdução, redigir claramente as questões que norteiam a pesquisa.

i) Expressar-se com propriedade: saber quando utilizar eu, nós e o impessoal na 
redação. Lembrando que a riqueza da pesquisa está na bagagem cultural que se cultiva.

j) Apresentar os resultados de forma criativa: $\grave{E}$ importante jogar o jogo da Universidade, mas também saber subvertê-lo, se necessário for. 